\title{
KETERLAKSANAAN PRAKTIK KERJA INDUSTRI SISWA SMK UNTUK MENJADI PEKERJA TEKNISI OTOMOTIF BERDASARKAN TUNTUTAN SKKNI
}

\author{
Fatra J. Purnama ${ }^{1}$, Inu H. Kusuma ${ }^{2}$, Mumu Komaro ${ }^{3}$ \\ Departemen Pendidikan Teknik Mesin \\ Universitas Pendidikan Indonesia \\ Jl. Dr. Setiabudhi No. 207 Bandung 40154 \\ fatra_jay@yahoo.com
}

\begin{abstract}
ABSTRAK
Penelitian ini bertujuan untuk mengetahui keterlaksanaan paraktik kerja Industri untuk menjadi seorang pekerja teknisi otomotif berdasarkan tuntutan SKKNI pada siswa kelas XII TSM SMK Negeri 8 Bandung. Metode yang digunakan dalam penelitian ini adalah metode deskriptif, dengan teknik pengumpulan data berupa angket dan observasi. Berdasarkan hasil pengolahan data menunjukkan bahwa keterlaksanaan praktik kerja industri sesuai dengan tuntutan SKKNI sudah berjalan dengan baik. Kriteria teknisi terbagi menjadi tiga tingkatan yaitu tingkat III atau Junior, tingkat II dan Tingkat I atau senior/master. Untuk kriteria teknisi otomotif berdasarkan keterlaksanaan praktik kerja industri sesuai tuntutan SKKNI hanya berlaku kepada teknisi tingkat III atau teknisi junior. Kriteria ini bisa tercapai karena standar kompetensi tingkat III atau junior ini sudah didapatkan siswa selama pembelajaran d kelas dan juga selama praktek kerja industri. Sedangkan untuk kriteria teknisi tingkat II dan tingkat I atau senior/master, standar kompetensinya hanya akan didapatka apabila siswa sudah bekerja sebagai teknisi dengan pengalaman dan training yang didapatkan di industri.
\end{abstract}

Kata kunci : prakerin, teknisi, otomotif, SKKNI

\section{PENDAHULUAN}

SMK N 8 Bandung adalah salah satu SMK unggulan di bandung yang memiliki kompetensi khusus di bidang otomotif. Untuk mendukung tujuan khusus dalam KTSP, SMK N 8 Bandung memiliki tujuan untuk meningkatkan kecerdasan, pengetahuan, kepribadian, akhlak mulia serta keterampilan untuk hidup mandiri dan mengikuti pendidikan lebih lanjut sesuai dengan kejuruannya. Visi dari sekolah SMK N 8 Bandung ini adalah menjadi Sekolah Unggulan yang menghasilkan tamatan berkualitas, sebagai mekanik/tenaga kerja yang kompeten, wirausahawan yang sukses dan melanjutkan ke perguruan tinggi melalui pengembangan IPTEK dan IMTAQ.

Salah satu indikator untuk mengukur ketercapaian tujuan dan visi dari SMK N 8 Bandung adalah dengan melihat sejauh mana lulusan bisa bekerja, berwirausaha dan melanjutkan kuliah dengan baik. Lulusan SMK N 8 Bandung yang bekerja di DU/DI dan

\footnotetext{
${ }^{1}$ Mahasiswa Departemen Pendidikan Teknik Mesin FPTK UPI

${ }^{2}$ Dosen Departemen Pendidikan Teknik Mesin FPTK UPI

${ }^{3}$ Dosen Departemen Pendidikan Teknik Mesin FPTK UPI
} 
instansi pemerintah adalah paling banyak di bandingkan dengan melanjutkan ke perguruan tinggi dan berwirausaha, tapi tidak semua yang bekerja di DU/DI dan instansi pemerintah ini adalah bekerja di perusahaan otomotif.

Siswa lulusan di SMK Negeri 8 Bandung yang telah bekerja di industri otomotif hanya terdapat 729 orang atau $79 \%$ dalam kurun waktu 3 tahun terakhir. Sisanya yaitu sebanyak 191 orang atau $21 \%$ telah bekerja diluar industri otomotif. Berdasarkan wawancara dengan Wakasek hubungan industri (HUBIN) SMK Negeri 8 Bandung menyatakan bahwa lulusan yang bekerja di industri otomotif maupun selain industri otomotif memang tidak dihitung nilai persentasinya. Tetapi dalam ini, SMK Negeri 8 Bandung adalah sekolah yang berkonsentrasi pada bidang otomotif, setidaknya minimal $85 \%$ yang bekerja adalah seharusnya bekerja pada industri otomotif.

Melihat kenyataan yang dihadapi tersebut, terdapat kesenjangan antara harapan dengan kenyataan, dimana harapannya adalah lulusan sekolah yang bekerja seharusnya minimal $85 \%$ bekerja di industri otomotif . Namun kenyataannya ternyata lulusan dari SMK N 8 Bandung dalam 3 tahun terakhir hanya terdapat $79 \%$ yang bekerja di industri otomotif, dan sisanya sebesar $21 \%$ bekerja diluar industri otomotif. Berdasarkan hal tersebut diperlukan sebuah solusi untuk mengatasi permasalahan tersebut. salah satu caranya adalah dengan menyelenggarakan Praktik Kerja Industri.

Praktik kerja Industri adalah suatu bentuk penyelenggaraan pendidikan keahlian kejuruan untuk peserta didik yang dilaksanakan di luar sekolah (industri) yang telah disesuaikan dengan kebutuhan di dunia usaha dan industri (Hamalik, 2007). Pelaksanaan praktek kerja industri secara tidak langsung akan memberikan pengetahuan dan pengalaman dalam bekerja. Pengalaman yang diperoleh pada saat melakukan praktik kerja industri secara tidak langsung akan mempercepat transisi siswa dari sekolah ke dunia industri. Praktik Kerja Industri dilaksanakan untuk memenuhi kebutuhan tenaga kerja yang profesional dibidangnya.

Pengukuran ketercapaian keberhasilan praktik kerja industri dapat dilihat dari hasil akhir atau nilai akhir praktek kerja industri itu sendiri. Nilai akhir dari seluruh siswa di SMK Negeri 8 Bandung telah memenuhi kriteria di atas KKM sebanyak 461 siswa atau 93\% dan yang belum memenuhi KKM sebanyak 32 siswa atau 7\%. Hasil ini menunjukkan bahwa kebanyakan siswa telah berhasil melaksanakan praktek kerja industri karena telah mendapatkan nilai di atas KKM. Namun nilai akhir praktek kerja industri yang telah terpenuhi 
ini tidak membuat siswa memiliki kriteria sebagai seorang teknisi otomotif, dikarenakan setiap teknisi otomotif mempunyai beberapa tingkatan atau level tertentu (Sudjana dan Ibrahim, 2010). Setiap tingkatan seorang teknisi mempunyai Standar Kompetensi yang sudah diterapkan oleh masing-masing industri. Untuk mencapai standar kompetensi tersebut, dibuat Standar Kompetensi Kerja Nasional Indonesia atau yang biasa dikenal dengan SKKNI.

SKKNI akan digunakan sebagai acuan dalam pembinaan, persiapan SDM yang berkualitas. Kompetensi yang diakui oleh seluruh pemangku kepentingan dan berlaku secara nasional di wilayah Negara Kesatuan Republik Indonesia. SKKNI adalah uraian kemampuan yang mencakup pengetahuan, keterampilan dan sikap kerja minimal yang harus dimiliki seseorang untuk menduduki jabatan tertentu yang berlaku secara nasional. Standar tersebut adalah acuan yang dibuat oleh industri yang digunakan untuk menetapkan tingkat kemampuan yang efektif dalam perawatan dan perbaikan di bengkel otomotif (Astra Honda Motor, 2004).

Praktik kerja industri di SMK Negeri 8 Bandung nampaknya belum terlaksana sesuai dengan tuntutan SKKNI. Siswa yang kebanyakan sudah memenuhi nilai akhir praktik kerja industri dengan baik tapi lulusannya masih banyak yang bekerja di luar industri otomotif (Petrus, 2004), karena belum sesuai dengan kriteria sebagai seorang teknisi otomotif. Penelitian ini bertujuan untuk mengetahui keterlaksanaan praktik kerja industri berdasarkan dengan tuntutan SKKNI; kriteria seorang pekerja teknisi otomotif siswa smk negeri 8 bandung; dan keterlaksanaan praktik kerja Industri siswa SMK untuk menjadi pekerja teknisi otomotif berdasarkan dengan tuntutan SKKNI.

Praktik kerja industri merupakan bagian dari prorgram pembelajaran yang harus dilaksanakan oleh setiap peserta didik, sebagai wujud nyata dari pelaksanaan sistim pendidikan di SMK. Program praktek kerja industri disusun bersama antara sekolah dan dunia kerja dalam rangka memenuhi kebutuhan peserta didik dan sebagai kontribusi dunia kerja terhadap pengembangan program pendidikjan SMK.

Standar Kompetensi Kerja Nasional Indonesia (SKKNI) akan digunakan sebagai acuan dalam pembinaan, persiapan SDM yang berkualitas, kompeten yang diakui oleh seluruh pemangku kepentingan (stake holder) dan berlaku secara nasional di wilayah Negara Kesatuan Republik Indonesia. SKKNI adalah uraian kemampuan yang mencakup pengetahuan, keterampilan dan sikap kerja minimal yang harus dimiliki seseorang untuk menduduki jabatan 
tertentu yang berlaku secara nasional. Standar tersebut adalah acuan yang dibuat oleh industri yang digunakan untuk menetapkan tingkat kemampuan yang efektif dalam perawatan dan perbaikan di bengkel otomotif. Standar tersebut merupakan kerangka kerja yang sesuai dengan kebutuhan semua pihak yang terkait, pemerintah, industri, lembaga pelatihan dan peserta pelatihan. Agar lebuh berdaya guna dan sesuai adalah penting bahwa pelatihan dan penilaian yang berhubungan dengan standar tersebut dilaksanakan dalam suatu cara yang dapat memenuhi kebutuhan khusus dari industri dan peserta pelatihan. Melalui cara ini pelatihan yang sebenarnya dibutuhkan oleh industri akan tercapai. Terdapat juga beberapa kegunaan dari standar kompetensi, contohnya sebagai dasar untuk: menyusun uraian pekerjaan, mengembangkan program pelatihan dan sumber daya manusia, menilai unjuk kerja seseorang, dan akreditasi profesi di tempat kerja.

Pengertian teknisi pada umumnya adalah seseorang yang menguasai bidang teknologi tertentu yang lebih banyak memahami teori bidang tersebut. Sedangkan otomotif adalah ilmu pengetahuan yang mempelajari tentang engine kendaraan bermotor seperti mobil dan motor. Berdasarkan dari beberapa pengertian di atas dapat diambil pengertian bahwa teknisi otomotif adalah seseorang yang menguasai bidang otomotif dan banyak memahami teori mengenai engine kendaraan bermotor. Pekerjaan teknisi otomotif adalah suatu jenis kegiatan yang dilakukan oleh manusia berdasarkan bidang keahlian yang berhubungan dengan engine (Al-Qahhar, 2012). Artinya seorang teknisi otomotif harus mampu menguasai bidang keahlian otomotif.

\section{METODE PENELITIAN}

Metode yang digunakan dalam penelitian ini adalah metode deskiptif yaitu hasil penelitian yang diperoleh kemudian diolah dan dianalisis untuk mengambil kesimpulan. Penelitian dengan menggunakan pendekatan kuantitatif. Pengumpulan data yang digunakan dalam penelitian ini adalah angket, studi literatur, dan studi dokumentasi. serta observasi. Data yang terkumpul selanjutnya diuji validitas dan realibilitasnya.

\section{HASIL PENELITIAN}

Objek dalam penelitian ini adalah siswa kelas XII TSM SMK Negeri 8 Bandung, pengambilan data dilakukan dengan cara menyebar instrument penelitian yakni instrument 
berupa angket mengenai keterlaksanaan praktek kerja industri berdasarkan tuntutan SKKNI, dan sebuah lembar observasi untuk mengetahui kriteria siswa sebagai calon seorang pekerja teknisi otomotif.

Proses pencarian data mengenai keterlaksanaan praktek kerja industri berdasarkan tuntutan SKKNI. yang terdiri dari 47 item pernyataan kepada 51 siswa SMK Negeri 8 Bandung. Berikut gambaran mengenai keterlaksanaan praktek kerja industri berdasarkan tuntutan SKKNI pada siswa kelas XII TSM SMK Negeri 8 Bandung.

Tabel 3.

Data Keterlaksanaan Praktek Kerja Industri berdasarkan Tuntutan SKKNI

\begin{tabular}{cccc}
\hline Rentang skor & Kategori & Frekuensi & Persentase(\%) \\
\hline $1,0-1,7$ & Tidak Baik & 0 & $0 \%$ \\
$1,8-2,5$ & Kurang Baik & 3 & $6 \%$ \\
$2,6-3,3$ & Cukup Baik & 5 & $10 \%$ \\
$3,4-4,1$ & Baik & 30 & $59 \%$ \\
$4,2-5,0$ & Sangat Baik & 13 & $25 \%$ \\
& Jumlah & 51 & $100 \%$ \\
\hline
\end{tabular}

Skor ideal rata-rata keterlaksanaan praktek kerja industri berdasarkan tuntutan SKKNI yaitu sebesar 3,83 (Tabel 1). Data ini tergolong ke dalam kategori baik, jika dilihat pada tabel 4.3 ada 30 siswa tergolong kedalam kategori baik, hal tersebut menunjukkan bahwa mayoritas siswa kelas XII TSM di SMK Negeri 8 Bandung telah melaksanakan praktek kerja industri berdasarkan tuntutan dari SKKNI dengan baik.

Proses pencarian data mengenai kriteria siswa di SMK Negeri 8 Bandung sebagai pekerja teknisi otomotif peneliti menggunakan cara observasi langsung kepada 10 siswa menggunakan lembar standar kompetensi pekerjaan teknisi otomotif sikap yang terdiri dari 3 kriteria, yaitu teknisi tingkat III, tingkat II dan tingkat I.

Bahwa dari 10 siswa yang sampelnya diambil dari 5 siswa dengan nilai tertinggi pada angket dan 5 siswa dengan nilai terendah pada angket (Tabel 2). Hasilnya menunjukan bahwa siswa masih berada pada kriteria baik sebanyak 6 orang pada tingkat teknisi junior dan 3 orang pada teknisi tingkat II, sedangkan untuk teknisi tingkat I atau senior belum ada siswa yang masuk dalam kategori baik. 
Tabel 2. Kriteria teknisi otomotif

\begin{tabular}{|c|c|c|c|c|c|c|c|c|c|c|}
\hline \multirow[t]{2}{*}{ No } & \multirow{2}{*}{$\begin{array}{l}\text { Nama } \\
\text { Siswa }\end{array}$} & \multicolumn{3}{|c|}{$\begin{array}{c}\text { Teknisi Tingkat III } \\
\text { (Teknisi Junior) }\end{array}$} & \multicolumn{3}{|c|}{ Teknisi Tingkat II } & \multicolumn{3}{|c|}{$\begin{array}{c}\text { Teknisi Tingkat I } \\
\text { Teknisi Senior/Master }\end{array}$} \\
\hline & & Skor & Persentasi & Kriteria & Skor & Persentasi & Kriteria & Skor & Persentasi & Kriteria \\
\hline 1 & $\mathrm{X} 1$ & 54 & $68 \%$ & Baik & 26 & $52 \%$ & $\begin{array}{c}\text { Cukup } \\
\text { baik }\end{array}$ & 20 & $40 \%$ & $\begin{array}{c}\text { Kurang } \\
\text { baik }\end{array}$ \\
\hline 2 & $\mathrm{X} 2$ & 50 & $63 \%$ & $\begin{array}{c}\text { Cukup } \\
\text { baik }\end{array}$ & 27 & $54 \%$ & $\begin{array}{c}\text { Cukup } \\
\text { baik }\end{array}$ & 16 & $20 \%$ & $\begin{array}{l}\text { Tidak } \\
\text { baik }\end{array}$ \\
\hline 3 & $\mathrm{X} 3$ & 47 & $58 \%$ & $\begin{array}{c}\text { Cukup } \\
\text { baik }\end{array}$ & 24 & $48 \%$ & $\begin{array}{c}\text { Kurang } \\
\text { baik }\end{array}$ & 18 & $36 \%$ & $\begin{array}{c}\text { Kurang } \\
\text { baik }\end{array}$ \\
\hline 4 & $\mathrm{X} 4$ & 50 & $63 \%$ & $\begin{array}{c}\text { Cukup } \\
\text { baik }\end{array}$ & 27 & $54 \%$ & $\begin{array}{c}\text { Cukup } \\
\text { baik }\end{array}$ & 22 & $44 \%$ & $\begin{array}{c}\text { Kurang } \\
\text { baik }\end{array}$ \\
\hline 5 & $\mathrm{X} 5$ & 57 & $71 \%$ & Baik & 24 & $48 \%$ & $\begin{array}{c}\text { Kurang } \\
\text { baik }\end{array}$ & 19 & $38 \%$ & $\begin{array}{c}\text { Kurang } \\
\text { baik }\end{array}$ \\
\hline 6 & $\mathrm{X} 6$ & 61 & $76 \%$ & Baik & 30 & $60 \%$ & $\begin{array}{c}\text { Cukp } \\
\text { baik }\end{array}$ & 24 & $48 \%$ & $\begin{array}{c}\text { Kurang } \\
\text { baik }\end{array}$ \\
\hline 7 & $\mathrm{X} 7$ & 64 & $80 \%$ & Baik & 34 & $68 \%$ & Baik & 25 & $50 \%$ & $\begin{array}{c}\text { Kurang } \\
\text { baik }\end{array}$ \\
\hline 8 & $\mathrm{X} 8$ & 64 & $80 \%$ & Baik & 37 & $74 \%$ & Baik & 28 & $56 \%$ & $\begin{array}{c}\text { Cukup } \\
\text { baik }\end{array}$ \\
\hline 9 & $\mathrm{X} 9$ & 65 & $81 \%$ & Baik & 39 & $78 \%$ & Baik & 29 & $58 \%$ & $\begin{array}{c}\text { Cukup } \\
\text { baik }\end{array}$ \\
\hline 10 & $\mathrm{X} 10$ & 49 & $61 \%$ & $\begin{array}{c}\text { Cukup } \\
\text { baik }\end{array}$ & 23 & $46 \%$ & $\begin{array}{c}\text { Kurang } \\
\text { baik }\end{array}$ & 16 & $32 \%$ & $\begin{array}{c}\text { Kurang } \\
\text { baik }\end{array}$ \\
\hline
\end{tabular}

\section{PEMBAHASAN}

Penelitian dilakukan pada siswa SMK Negeri 8 Bandung tahun ajaran 2014/2015, dimana jumlah responden yang menggunakan angket sebanyak 51 siswa jurusan Teknik Sepeda Motor, sedangkan untuk observasi hanya di ambil 10 siswa dengan cara mengambil 5 nilai siswa tertinggi dan 5 siswa terendah. Pembahasan hasil penelitian ini dimaksudkan untuk memberikan gambaran dan pemahaman dari hasil yang diperoleh dalam penelitian.

Instrumen penelitian yang digunakan untuk mencari data adalah angket dan observasi. Jumlah keseluruhan item untuk angket adalah sebanyak 47 item soal dengan 47 item, sedangkan untuk lembar observasi menggunakan tiga kriteria tingkatan standar kompetensi pekerjaan teknisi otomotif, yaitu teknisi tingkat III atau teknisi junior, teknisi tingkat II dan teknisi tingkat I atau teknisi Senior/master. 
Hasil yang diperoleh dari penelitian menunjukkan bahwa keterlaksanaan Praktek Kerja Industri berdasarkan tuntutan SKKNI di kalangan siswa kelas XII TKR SMK Negeri 8 Bandung, dari 51 siswa didapat hasil sebanyak 3 siswa (6\%) termasuk kedalam kategori kurang baik, 5 siswa (10\%) termasuk kedalam kategori cukup baik, 30 siswa (59\%) termasuk kedalam kategori baik dan 13 siswa (25\%) termasuk kedalam kategori siswa sangat baik, jika dilihat dari rata-rata skor ideal yaitu sebesar 3,83 nilai tersebut termasuk kedalam kategori baik Data tersebut merupakan temuan yang menunjukkan sebagai gambaran atau tingkat keterlaksanaan praktek kerja industri berdasarkan tuntutan SKKNI di kalangan siswa kelas XII TSM SMK Negeri 8 Bandung itu berada dalam kategori baik.

Data diatas menunjukkan bahwa tingkat keterlaksanaan praktek kerja industri berdasarkan tuntutan SKKNI tergolong kedalam kategori baik. Artinya bahwa masih banyak siswa yang melaksanakan pekerjaan-pekerjaan ketika praktek industri berdasarkan tuntutan dari SKKNI. Terlaksananya tuntutan SKKNI pada praktek kerja industri secara baik ini menggambarkan bahwa siswa di SMK Negeri 8 Bandung khususnya jurusan Teknik Sepeda Motor selalu mengikuti aturan-aturan yang ada di industri. Tuntutan SKKNI ini diterapkan di industri tentunya bertujuan untuk menetapkan tingkat kemampuan yang efektif dalam perawatan dan perbaikan di bengkel sepeda motor.

Hasil yang diperoleh dari penelitian menunjukkan bahwa siswa kelas XII TSM SMKN 8 Bandung dari 10 siswa pada kriteria teknisi tingkat III atau teknisi junior didapat hasil sebanyak 6 siswa termasuk kedalam kategori baik (68\%-84\%), 4 siswa termasuk kedalam kategori cukup baik (52\%-68\%). Untuk teknisi tingkat II didapat hasil 4 siswa termasuk kedalam kategori siswa yang memiliki kategori baik (68\%-84\%), 4 siswa termasuk kedalam kategori cukup baik (52\%-68\%), dan 2 siswa berada dalam kategori kurang baik (36\%-52\%). Teknisi Tingkat I atau Teknisi senior/Master didapat 2 siswa dalam kategori cukup baik (52\%68\%), 7 siswa dalam kategori kurang baik (36\%-52\%) dan 1 siswa dalam kategori tidak baik $(20 \%-36 \%)$.

Data tersebut merupakan temuan yang menunjukkan sebagai gambaran tingkat kemampuan atau kriteria seorang pekerja teknisi otomotif pada kalangan siswa kelas XII TSM SMK Negeri 8 bandung. Dari data tersebut menunjukan bahwa terdapat 6 siswa yang berkategori baik pada teknisi tingkat III atau teknisi junior, itu artinya siswa yang telah selesai melaksanakan praktek industri berdasarkan tuntutan SKKNI sudah bisa dikategorikan sebagai 
teknisi junior, karena sebagian pekerjaan seorang teknisi junior sudah bisa dilakukan dengan baik oleh siswa.

Untuk Teknisi tingkat II, hanya ada 3 orang yang memiliki kriteria baik, sisanya berada dalam kategori cukup baik sebanyak 4 siswa dan kurang baik sebanyak 3 siswa. Artinya hanya sebagian kecil yang memiliki kriteria sebagai teknisi tingkat II, dimana hal ini menunjukan bahwa untuk masuk kategori teknisi tingkat II, seorang siswa masih butuh banyak pengalaman untuk meningkatkan kemampuan dari teknisi tingkat III (Teknisi Junior). Sedangkan kategori Teknisi Tingkat I (senior/ master) belum ada siswa yang memiliki kriteria baik, hal ini bisa dimengerti karena untuk mencapai level ini butuh pengalaman yang cukup lama, karena jika hanya mengandalkan selama beberapa bulan ketika praktek industri tidak akan mampu mencapai kriteria Teknisi Senior ini.

Hasil penelitian keterlaksanaan praktik kerja industri berdasarkan dengan tuntutan SKKNI adalah terlaksana dengan baik. Lalu dari terlaksananya SKKNI tersebut, dilakukan penelitian dengan cara observasi terhadap siswa yang bersangkutan dengan sejulah sampel sebanyak 10 siswa. Hasil ini menunjukan bahwa siswa yang telah melaksanakan praktek kerja industri berdasarkan tuntutan SKKNI sudah memiliki kriteria sebagai Teknisi Tingkat III atau teknisi junior. Untuk teknisi tingkat II hanya sebagian yang memiliki kriteria, sedangkan untuk Teknisi tingkat III atau senior/master belum ada satupun siswa yang memiliki kriteria tersebut.

Siswa yang telah melaksanakan praktek kerja industri dan sesuai dengan tuntutan SKKNI sudah layak menjadi seorang teknisi otomotif namun hanya pada tingkat III atau teknisijunior. Hal ini bisa terjadi karena standar kompetensi untuk teknisi tingkat III atau junior sudah siswa dapatkan dalam materi ketika mereka belajar dalam pembelajaran di kelas. Adapun beberapa standar kompetensi untuk teknisi tingkat III ini diantaranya adalah memahami nama, fungsi dan cara menggunakan alat tangan, alat ukur yang memang secara teori dan praktek sudah siswa dapatkan ketika mereka belajar di kelas. Selain itu beberapa standar kompetensi yang lain seperti fungsi dan cara kerja komponen sistem engine, powertrain, chasis dan kelistrikan pun sudah mereka dapatkan ketika pembelajaran d kelas. Berdasarkan hal tersebut maka sudah sepantasnya seorang siswa yang telah melaksanakan praktik kerja industri berdasarkan tuntutan SKKNI bisa memiliki kriteria sebagai seorang Teknisi Tingkat III atau seorang teknisi junior. 
Siswa yang memiliki kriteria baik sebagai teknisi tingkat II dalam penelitian ini dimiliki oleh 3 orang, sedangkan sisanya sebanyak 7 siswa belum memiliki kriteria sebagai teknisi tingkat II. Adapun standar kompetensi pada teknisi tingkat II ini diantaranya adalah menguasai karakteristik kerja komponen dan sistem pada engine, powertrain, chasis dan electrical, memahami hubungan kerja antara sistem-sistem tersebut, mampu menganalisa kerusakan pada komponen , mampu membedakan peralatan dan komponen yang asli dan palsu,serta mampu merawat dan memperbaiki sistem atau komponen elektronik dengan benar. Beberapa standar kompetensi tersebut tidak siswa dapatkan di kelas sebelumnya, dikarenakan standar kompetensi untuk seorang teknisi tingkat II ini adalah pengembangan dari beberapa mata pelajaran yang telah didapatkan di kelas. Oleh karena itu sebagian siswa belum memiliki kriteria sebagai seorang teknisi tingkat II, sedangkan beberapa siswa yang memiliki kriteria tersebut bisa disebabkan mereka lebih mendalami kegiatan kerja di bengkel di luar pelajaran yang mereka dapatkan di sekolah.

Teknisi tingkat I atau teknisi senior/master tidak bisa didapatkan hanya dari pengalaman d sekolah dan praktek kerja industri, walaupun sudah sesuai dengan tuntutan dari SKKNI. Hal ini disebabkan standar kompetensi untuk Teknisi Tingkat I atau Teknisi Senior/master bukan lagi yang siswa dapatkan di sekolah ataupun selama praktek industri. Salah satu contoh standar kompetensi pada teknisi tingkat I ini adalah menguasai perkembangan teknologi bidang otomotif, mampu beradaptasi dengan teknologi baru pada semua sistem, mampu mencari solusi pemecahan dari permasalahan yang timbul, mampu menganalisa gangguan pada sistem dan menemukannya secara sistematis, mampu memodifikasi komponen atau sistem yang sesuai dan dapat menyusun langkah yang efektif untuk melakukan pekerjaan baru dan solusi yang baru.

Beberapa dari standar kompetensi tingkat I atau teknisi senior/master ini tentu saja tidak mudah dimiliki oleh siswa yang hanya telah melaksanakan praktek kerja sesuai tuntutan SKKNI. Karena untuk mempunyai standar kompetensi teknisi tingkat senior atau master ini yaitu dengan memiliki pengalaman kerja sebagai seorang teknisi di bengkel dengan kurun waktu yang cukup lama dan telah mengikuti beberapa training yang diadakan oleh industri tersebut. Hal inilah yang menyebabkan siswa yang telah melaksanakan praktek industri dan sesuai dengan SKKNI dengan baik sekalipun belum cukup untuk memiliki kriteria sebagai seorang teknisi tingkat I atau teknisi senior/master. 
Kompetensi teknisi ditampilkan dalam tiga hal yang terkait antara satu dengan yang lainnya yaitu: knowledge (pengetahuan), skill (kemampuan), dan attitude (sikap dan etos kerja) (Shinduwinata, 2001). Ketiga komponen teknisi tersebut dapat diklasifikasikan menjadi beberapa level teknisi dengan tuntutan kemampuan yang bervariasi untuk melakukan pekerjaan yang dihadapi di bengkel. Hasil penelitian ini sesuai dengan pengklasifikasian Badan Pusat Statistik (2002), bahwa kriteria utama dalam pengklasifikasian jenis pekerjaan dalam golongan pokok adalah tingkat keahlian. Sedangkan untuk golongan, subgolongan, kelompok dan jenis pekerjaan dibedakan berdasarkan kriteria spesialisasi keahlian dengan interpretasi secara luwes.

\section{KESIMPULAN}

Kesimpulan penelitian ini yaitu: mayoritas siswa kelas XII TSM di SMK Negeri 8 Bandung telah melaksanakan praktek kerja industri berdasarkan tuntutan dari SKKNI dengan baik. Pekerjaan teknisi otomotif terdiri dari tiga tingkatan, yaitu Teknisi Tingkat III atau teknisi junior, teknisi tingkat II dan teknisi tingkat I atau teknisi senior/master. Keterlaksanaan praktek kerja industri untuk menjadi seorang pekerja teknisi otomotif berdasarkan tuntutan SKKNI hanya mampu mencapai kategori teknisi tingkat III atau pemula. Untuk teknisi tingkat II dan Tingkat I atau senior/master diperlukan pengalaman lebih lama sebagai teknisi serta training dari pihak industri tersendiri.

\section{DAFTAR PUSTAKA}

Al-Qahhar, R. S. (2012). Klasifikasi dan Pengertian Pekerjaan. [Online]. Tersedia: http://bloggercompecintabahasa.blogspot.com/2012/09/klasifikasi-dan-pengertianpekerjaan.html. [9 Juli 2013].

Astra Honda Motor. (2004). Team AHASS. Jakarta: PT. Astra Honda Motor.

Badan Pusat Statistik. (2002). Klasifikasi Baku Jenis Pekerjaan Indonesia (KBJI). Jakarta: CV. Nario Sari.

Hamalik, O. (2007). Praktek Kerja Industri. Jakarta: PT Raja Grafindo Persada.

Petrus, E. (2004). Menyiasati praktek kerja industri untuk sekolah menengah kejuruan. Bandung: CV moefh Design 
Sindhuwinata, G. (2001). Peran Bengkel Otomotif Terhadap Sistem Transportasi Nasional yang Aman. Bandung: Indomobil Grup.

Sudjana, N. dan Ibrahim. (2010). Penelitian dan Penilaian Pendidikan. Bandung: Sinar Baru Algensindo. 